\title{
NEW OR INTERESTING RECORDS OF THREE BUTTERFLY (LEPIDOPTERA: PAPILIONOIDEA \& HESPERIOIDEA) SPECIES FROM BOSNIA AND HERZEGOVINA AND CROATIA
}

\author{
Toni Koren ${ }^{1}$ \& Dejan Kulijer ${ }^{2}$ \\ ${ }^{1}$ Association Hyla, I. Lipovac 7, HR-10000 Zagreb, Croatia (e-mail: koren.toni1@gmail.com) \\ ${ }^{2}$ National Museum of Bosnia and Herzegovina, Zmaja od Bosne 3, 71000 Sarajevo, Bosnia \\ and Herzegovina (e-mail: dejan.kulijer@gmail.com)
}

Koren, T. \& Kulijer, D.: New or interesting records of three butterfly (Lepidoptera: Papilionoidea \& Hesperioidea) species from Bosnia and Herzegovina and Croatia. Nat. Croat., Vol. 25, No. 2., 321-326, 2016, Zagreb.

Three butterfly species were recorded for the first time for the fauna of Bosnia and Herzegovina in the Herzegovina region: Danaus chrysippus, Cacyreus marshalli and Carcharodus orientalis. The records represent expansions to the known distribution, although the presence of all three species was expected as they are to be found in neighbouring countries. This is the third record that D. chrysippus has reached southern Croatia, and the first time it has been observed in Bosnia and Herzegovina. The record of the non-native $C$. marshalli fills the distributional gap, and the record of C. orientalis, a rare and local species in the region, represents an increase of the known distribution in the mainland of the western Adriatic coastline. In the future, additional records of rare and unrecorded species are expected in the country.

Key words: Carcharodus orientalis, Cacyreus marshalli, Danaus chrysippus, Herzegovina, new country records

Koren, T. \& Kulijer, D.: Novi i zanimljivi nalazi tri danja leptira (Lepidoptera: Papilionoidea \& Hesperioidea) za faunu Bosne i Hercegovine te Hrvatske. Nat. Croat., Vol. 25, No. 2., 321-326, 2016, Zagreb.

Tri vrste danjih leptira zabilježene su po prvi puta za faunu Bosne i Hercegovine na području Hercegovine: Danaus chrysippus, Cacyreus marshalli i Carcharodus orientalis. Ti nalazi predstavljaju tek maleno povećanje poznate rasprostranjenosti te su sukladno tome i očekivani, budući da su vrste znane iz susjednih država. Ovo je treći put da je zabilježeno da je D. chrysippus dosegao južnu Hrvatsku, i prvi puta da je vrsta opažena u Bosni i Hercegovini. Nalaz invazivnog plavca C. marshalli popunjava prazninu u rasprostranjenosti te vrste, dok nalaz C. orientalis, rijetke i lokalne vrste, predstavlja povećanje poznate rasprostranjenosti na kopnenom dijelu zapadne obale Jadranskoga mora. U budućnosti se očekuju dodatni nalazi rijetkih i do sada nezabilježenih vrsta leptira.

Ključne riječi: Carcharodus orientalis, Cacyreus marshalli, Danaus chrysippus, Hercegovina, novi nalazi za državu

The first checklist of the butterfly fauna of Bosnia and Herzegovina $(\mathrm{BiH})$ was published more than a century ago (REBEL, 1904). Afterwards, a significant number of publications dealing with different aspects of butterfly fauna appeared (for details see LELO, 2000). Recently, a monograph about the butterfly fauna of the country was published containing 190 species with notes on doubtful occurrences (LELO, 2008). Afterwards, 
Proterebia afra dalmata (Godart, 1824) (Konen \& TRкоv, 2011), Melitaea britomartis Assmann, 1847 (Koren \& Jugovic, 2012) and Polyommatus aroaniensis (Brown, 1976) (VERovnik et al., 2015) were discovered in BiH for the first time. Interestingly, in the most recent work, in which most of the mentioned species were included, only 189 species were mentioned (Lelo et al., 2015). However, in a paper published in the same year, dealing with the revision of the Nymphalide family in the country, the record of $M$. britomartis was not mentioned (Lelo \& HaNJalić, 2015), and was even excluded from the list (LeLo, 2013) based on the European butterfly atlas (KudRnA et al., 2011). This suggests that a revision of the list of butterflies of the country is needed in order to establish the correct number of species.

During 2016 we visited the southern part of Bosnia and Herzegovina and recorded three butterfly species that have never before been recorded in the country. Butterflies were caught with an entomological net, or observed in their habitat. All the butterflies caught were examined, photographed if possible, and released afterwards. The identification was done using Tolman \& Lewington (2008). For each species, the exact locality, coordinates, date, observer and additional notes are provided.

\section{Danaus chrysippus (Linnaeus, 1758)}

Material examined: Bosnia and Herzegovina, between the Klek border crossing and Neum City, 08.10.2016, N: 42.935005 ${ }^{\circ}$, E: $17.586944^{\circ}, 21 \mathrm{~m}$ a.s.1., 1 ex. in flight/on the ground, obs. \& ident. Dejan Kulijer. A single specimen was observed flying for a short time along the road and circling over nearby grassy vegetation. After landing just for a second it was disturbed by a passing car and disappeared among the bushes below the road, towards the coast.

Croatia \& Bosnia and Herzegovina, south-east of Klek settlement, 23.09.2016., N: $42.938457^{\circ}$, E: $17.565536^{\circ}, 0 \mathrm{~m}$ a.s.l., 1 ex. in flight, obs. \& ident. Dejan Kulijer. On $23^{\text {rd }}$ September, at mid-day with sunny weather and a gentle breeze, one specimen was observed flying slowly (gliding) $0.5 \mathrm{~m}$ above the surface of the sea acros Neum Bay. As the

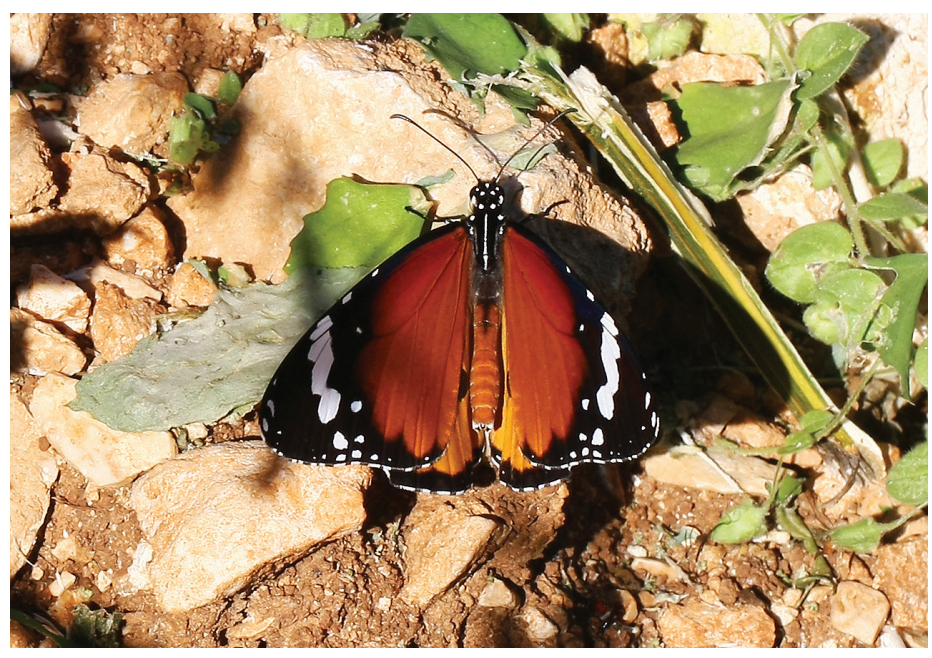

Fig. 1. Danaus chrysippus from the surroundings of Klek (photo: D. Kulijer). 
day was clear without any noticeable wind and the butterfly was flying slowly in a straight line, it could be followed by eye for some time and seen nicely against the contrasting background of the calm sea and rocks on the coast. It was observed in Croatia flying across the bay, entering the territory of $\mathrm{BiH}$ and flying away towards the central part of Klek Peninsula.

Croatia, Klek, $05.10 .2016, \mathrm{~N}: 42.947612^{\circ}$, E: $17.563305^{\circ}, 26 \mathrm{~m}$ a.s.l., 2 ex. in flight/on ground, obs. \& ident. Dejan Kulijer. Two specimens were observed on dry grassland at the margin of the settlement. Both spent a few minutes at the site, with several brief stops on small patches of bare ground in an area with low vegetation (Fig. 1).

Note: The closest records of this migratory species are known from Croatia (Perković, 2006) and Montenegro (JAKšić \& Ristić, 1999). In Croatia it was recorded in two separate areas, the Neretva River delta in 2004 (Perković, 2006) and 2007 (D. Kitonić, pers. obs.) as well as on Mljet Island in 2007 (Kučınić et al., 2010). As it is also rare species in Croatia we provided details on the observations also for Croatia. As far as we know, this is the third event in which specimens have reached southern Croatia, and the first time that they have been observed in the territory of Bosnia and Herzegovina. Further records are expected in the future in other parts of the Adriatic coast, as well as in the warmer parts of the mainland of southern Croatia and Bosnia and Herzegovina. This is a new species for the fauna of Bosnia \& Herzegovina.

\section{Cacyreus marshalli Butler, 1898}

Material examined: Bosnia and Herzegovina, Neum town, 21.06.2016., N: 42.926829, E: $17.614110^{\circ}, 68 \mathrm{~m}$ a.s.1., 2 ex., obs. \& coll. Toni Koren.

Note: This originally South African species is rapidly spreading across Europe. In 2001 it was recorded for the first time in Croatia on Lošinj Island (Kosmač \& VerovniK, 2009). Thereafter it become widespread and now inhabits a large number of the Adriatic islands, as well as most of the coastal areas of Croatia (Kučinić et al., 2014, Koren, pers. obs.). The species is also widespread in the coastal and sub-Mediterranean parts of Slovenia (Verovnik et al., 2011). Accordingly, it is not surprising that the species has been recorded in the southern part of Bosnia and Herzegovina. Only two specimens were noted, during a short stop in Neum Town. Also, its larval food plants, Pelargonium spp., were present in the town on the balconies of several houses. Additional surveys of the western Adriatic coastline would probably reveal additional localities for this species in the country, especially along the River Neretva, further in the mainland. This is a new species for the fauna of Bosnia and Herzegovina.

\section{Carcharodus orientalis Reverdin, 1913}

Material examined: Bosnia and Herzegovina, Stolac, old town, 02.08.2016., N:

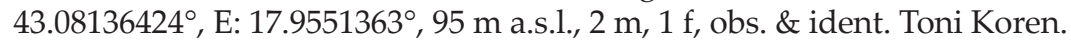

Note: This is a southern species, distributed from Dalmatia in Croatia, across Montenegro, Albania, Republic of Macedonia, Bulgaria, Greece and European Turkey (ToLMAN \& Lewington, 2008). Nearby records originate from Croatia, where the species is locally distributed from northern Dalmatia (VEROvNIK et al., 2015) towards southern Dalmatia (LoRкоvić, 2009). In general, it is a rare and local species. As with other skippers, the correct identification can be somewhat problematic, as it can easily be confused with the very similar Carcharodus floccifera (Zeller, 1847) from which it can be reliably distinguished due to the prominent dark tuft of hair on the underside of the front wings 


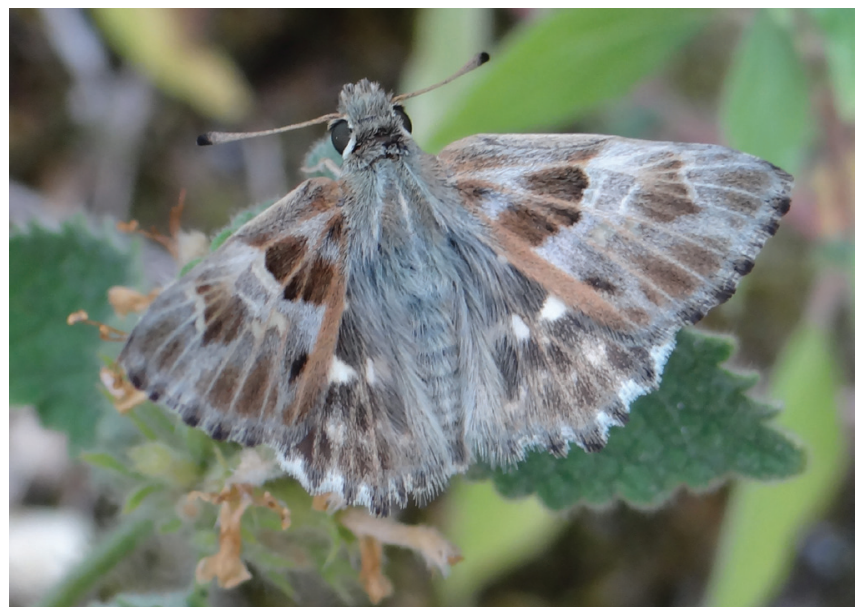

Fig. 2. Carcharodus orientalis from the surroundings of Stolac (photo: T. Koren).

in males (Tolman \& Lewington, 2008). One male specimen was caught, and the presence of the mentioned dark tuft was confirmed. Additionally, there is a strong habitat separation, with $C$. orientalis inhabiting dry karstic habitats and C. floccifera being usually present in more humid habitats. The habitat on which it was recorded represents typical Mediterranean slopes, with a mixture of different degradation states of maquis and small patches of dry grasslands in between. Also, there are many more fragments of this kind of habitat around the ruins and on other part of the hill. Our record from Stolac expands the known distribution of the species toward the mainland of Herzegovina, and implies that further populations will probably be discovered in other localities in the country. This is a new species for the fauna of Bosnia and Herzegovina.

With further surveys, especially of the southern and eastern part of Bosnia and Herzegovina further records of new and interesting species are to be expected. For example, Pyronia ecilia (Vallantin, 1894), a rather common, but locally distributed species across the eastern Adriatic coastline has still not been recorded (LeLO, 2008), but can be expected somewhere in the Mediterranean part of the country.

\section{Acknowledgments}

The first author is grateful to the organizers of the Sixth Stolac International Biology Camp during which Carcharodus orientalis was recorded. Acknowledgments are also due to Rudi Verovnik for the help with the identification of C. orientalis, and to Mladen Zadravec for help with the manuscript.

Received October 12, 2016

\section{REFERENCES}

JAKšıć, P. \& Ristić, G., 1999: New and rare species of Lepidoptera in Yugoslavia. Acta entomol. Serb. $4(1 / 2), 63-74$.

Koren, T. \& Jugovic, J., 2012: New data on the presence of three similar species of the genus Melitaea: M. athalia, M. aurelia and M. britomartis (Lepidoptera: Nymphalidae) in the North-Western Balkans. Ann. Ser. Hist. Nat. 22(1), 25-34. 
Koren, T., \& Trkov, D., 2011: Proterebia afra damlata (Godart, 1824) (Lepidoptera, Satyrinae) recorded for the first time in Bosnia and Herzegovina. Nat. Slov. 13(2): 57-58.

Kosmač, M. \& Verovnik, R., 2009: First record of Cacyreus marshalli (Lycaenidae) from the Balkan Peninsula. Nota lepidopterol. 32(1), 81-82.

Kučinić, M., Minoci, I., Tvrtković, N., ŠAšıć, M., Bojanić, D., Joković, S., Mazija, M. \& Popijač, A., 2010 : Butterfly Diversity (Insecta: Lepidoptera, Rhopalocera) of the Island of Mljet, Croatia. Proc. Symp. Branimir Gušić Days, Mljet, 111-125 pp.

Kučinić, M., Randić, M., Minoci, I., Koren, T., Mrnjavčić Vojvoda, A., Lauš, B. \& Burić, I., 2014: Contribution to knowledge of the distribution of the Geranium Bronze Cacyreus marshalli (Butler, 1898) (Lepidoptera, Lycaenidae) in Croatia with note on ecology and ethology. Ent. Croat. 18(1-2), 49-57.

Kudrna, O., Harpke, A., Lux, K., Pennerstorfer, J., Schweiger, O., Settele, J. \& Wiemers, M., 2011 : Distribution atlas of butterflies in Europe. Geselschaft für Schmetterlingsschutz e.V., Halle, 276 pp.

Lelo, S., 2000: Revised inventory of the butterflies of Bosnia and Herzegovina (Insecta: Lepidoptera: Hesperioidea, Papilionoidea). Nat. Croat. 9(2), 139-156.

Lelo, S., 2008: Dnevni leptiri Bosne i Hercegovine (Lepidoptera: Papilionoidea i Hesperioidea): Ključ za determinaciju vrsta sa osnovnim monografskim podacima. Univerzitetska knjiga. Prirodnomatematički fakultet Univerziteta u Sarajevu, 333 pp.

Lelo, S., 2013: Pogrešni navodi za bosanskohercegovačku faunu dnevnih leptira (Hesperioidea, Papilionoidea) u Atlasu rasprostranjenja dnevnih leptira Evrope Kudrne i saradnika iz 2011. godine. Prilozi fauni Bosne i Hercegovine 9, 67-71.

Lelo, S., KAšıć-Lelo, M. \& AbAZA, A., 2015: Novi nalazi grčkog neobičnog plavca, Polyommatus aroaniensis (Brown, 1976) (Papilionidae: Lycaenidae: Polyomatinae), u Bosni i Hercegovini. Prilozi fauni Bosne i Hercegovine, 11, 35-40.

Lelo, S. \& Hanjalıć, J., 2015: Revizija taksonomsko-klasifikacijskog prijegleda bosanskohercegovačkih šarenjaka: Nymphalidae Rafinesque, 1815 (Lepidoptera: Papilionoidea). Prilozi fauni Bosne i Hercegovine 11, 91-98.

Lorković, Z., 2009: (unpublished manuscript from 1954): Rhopalocera fauna of Croatia with special respect to the fauna of Plitvice Lakes. Ent. Croat. 13, 15-78.

Perković, D., 2006: Danaus chrysippus (Linnaeus, 1758) (Lepidoptera, Nymphalidae, Danainae), a new species in the fauna of Croatia. Nat. Croat. 15(1-2), 61-64.

Rebel, H., 1904: Studien über die Lepidopterenfauna der Balkanländer. II. Teil. Bosnien und Herzegowina. Ann. Naturh. Mus. Wien 19, 97-377 + Taf. IV-V.

Tolman, T. \& Lewington, R., 2008: Collins butterfly guide. HarperCollins Publishers, London, 384 pp.

Verovnik, R., Franeta, F., Popović, M. \& Gascoigne-Pees, M., 2015: The discovery of Polyommatus aroaninensis (Brown, 1976) in Bosnia and Herzegovina (Lepidoptera: Lycaenidae). Nachrichten des Entomologischen Vereins Apollo 36(4), 177-180.

Verovnik, R., Polak, S. \& Seljak, G., 2011: Pojav in širenje tujerodne vrste dnevnega metulja - pelargonijevega bakrenčka (Cacyreus marshalli (Butler, 1898)) v Sloveniji. Acta Entomol. Slov. 19(1), 5-16.

Verovnik, R., Koren, T. \& Glavan, G., 2015: Contribution to the knowledge of the butterfly and skipper fauna of northern Dalmatia mainland. Nat. Croat. 24(2), 265-280.

\title{
SAŽETAK
}

\section{Novi i zanimljivi nalazi tri danja leptira (Lepidoptera: Papilionoidea \& Hesperioidea) za faunu Bosne i Hercegovine te Hrvatske}

\author{
T. Koren \& D. Kulijer
}

Fauna danjih leptira Bosne i Hercegovine (BiH) istražuje se već preko 100 godina, no popis vrsta je još uvijek nepotpun. U zadnjih desetak godina pronađeno je nekoliko dotad nezabilježenih vrsta poput Proterebia afra dalmata (Godart, 1824) (Koren \& TrKov, 2011), Melitaea britomartis Assmann, 1847 (Koren \& Jugovic, 2012) te Polyommatus aroaniensis (Brown, 1976) (Verovnik i sur., 2015). Tijekom nekoliko posjeta Hercegovini u 2016. godini zabilježene 
su tri do sada nezabilježene vrste danjih leptira za Bosnu i Hercegovinu: Danaus chrysippus, Cacyreus marshalli i Carcharodus orientalis. Monarh, D. chrysippus, bio je zabilježen na delti Neretve i otoku Mljetu u Hrvatskoj (Perković, 2006; Kučınić i sur., 2010). Nalaz iz Kleka predstavlja novi nalaz ove vrste u Hrvatskoj, dok nalazi iz BiH predstavljaju prve nalaze ove vrste u državi. Nalaz alohtonog plavca Cacyreus marshalli u Kleku popunjava prazninu u rasprostranjenosti ove vrste, koja je od 2009. godine, kada je zabilježena u Hrvatskoj na otoku Lošinju, proširila svoj areal preko gotovo cijele sjeverozapadne obale Jadrana, a sada je stigla i do BiH. Nalaz debeloglavca Carcharodus orientalis, rijetke i lokalne vrste, u okolici Stoca predstavlja prvi nalaz ove vrste u BiH. Daljnjim istraživanjima zasigurno će se pronaći novi lokaliteti za sve tri novozabilježene vrste unutar države. Isto tako, novi nalazi rijetkih i dosad nezabilježenih vrsta očekuju se u daljnjim istraživanjima danjih leptira $\mathrm{BiH}$. 